\title{
The Institutionalisation of Comparative Education in Asia and the Pacific: Roles and Contributions of Comparative Education Societies and the WCCES
}

\author{
Mark Bray $^{\mathrm{a} *}$ and Maria Manzon ${ }^{\mathrm{b}}$ \\ ${ }^{a}$ Comparative Education Research Centre, Faculty of Education, The University of Hong Kong, China; \\ ${ }^{b}$ Office of Education Research, National Institute of Education, Singapore
}

\begin{abstract}
The institutional framework of the field of comparative education has developed significantly in recent decades. One manifestation of development has been the establishment and activities of professional societies. This paper focuses on 12 societies that operate in Asia and the Pacific. Some of these societies have long histories while others are recent creations. The paper considers the geographic and conceptual remits of these societies, and their activities including organisation of conferences and publication of journals. Patterns are viewed through the lenses of literature on intellectual fields and on academic tribes and territories.
\end{abstract}

Keywords: comparative education; academic disciplines and fields; professional societies and associations; Pierre Bourdieu - intellectual field

\section{Introduction}

The starting point for this article is a volume of histories of the World Council of Comparative Education Societies (WCCES) and its members (Masemann, Bray \& Manzon, 2007). Part I of that volume presented chapters on the history of the WCCES, noting that it had been established in 1970 as an umbrella body to bring together five national and regional societies of comparative education. By 2007, the book noted (p.4), the WCCES had 36 member societies. Part II of the book presented histories of 21 of these societies in individual chapters and shorter accounts of 15 societies in a single chapter. Part III proceeded to interpretation of patterns. It included commentary on dimensions of disciplinary institutionalisation, taken to mean the creation of a distinct sphere of scientific activity (Wagner \& Wittrock, 1991, p.3), and scholarly networking, of which the activities of scholarly societies are one form. The WCCES book and this article focus on comparative education societies as the unit for analysis in elucidating the institutionalisation of comparative education.

One contribution of this paper is an update of accounts. During the period since preparation of the book (Masemann et al., 2007), patterns have evolved in significant ways. Most societies have remained active, but some have become dormant and others have been revitalised. In addition some new societies have been formed, including one in the Asia-Pacific region. These changes have introduced new variations in geographic coverage and stimulus to the field. Denman and Higuchi (2013) noted a continuing gap in the literature about the history,

*Corresponding author. Email: mbray@hku.hk 
purpose and direction of comparative education research in Asia and the Pacific. This paper reduces the gap with respect to the institutionalisation of comparative education in the form of scholarly societies in this geographic region.

The paper begins with the literature about scholarly fields of enquiry and the value of academic networks. It particularly focuses on the work on academic tribes and territories by Becher and Trowler (2001) and the theoretical framework on intellectual fields presented by Bourdieu (1969, 1975, 1977). It then considers methodological dimensions of units for analysis, presenting the professional societies of comparative education in the Asia-Pacific region and noting some characteristics. Following these sections, the paper remarks first on the role of the WCCES as facilitator, legitimator and gate-keeper, and then on the activities of the comparative education societies and particularly their conferences and publications. The final section draws threads together by returning to the conceptual framework and noting the wider implications of patterns and processes.

\section{Academic Tribes and Territories}

The vocabulary of academic tribes and territories was given currency by a book of that name written by Becher (1989). A dozen years later, the book appeared in second edition, co-authored by Becher and Trowler (2001); and nearly another dozen years after that, Trowler and colleagues charted further evolving patterns (Trowler, Saunders \& Bamber, 2012).

The tribes to which these books referred were academic communities that were defined partly by the members of those communities and partly by universities which placed them in faculties, departments, centres or other units. The territories were the disciplinary knowledge characteristics, i.e. the ideas on which the academics focused, including subject matter, methods, and modes of discourse. The subtitle of the 1989 and 2001 books referred to the cultures of disciplines. Becher and Trowler (2001, p.23) defined cultures as "sets of taken-for-granted values, attitudes and ways of behaving, which are articulated through and reinforced by recurrent practices among a group of people in a given context”. The academic practices of specific tribes, the authors argued, both shape and are shaped by the academic territories they occupy. The principal focus of the book was on "practitioners in a dozen disciplines whose livelihood it is to work with ideas ... [which] lend themselves to sustained exploration, and which form the subject matter of the disciplines in question” (p.23).

This quotation raises a question about the nature of disciplines. Becher and Trowler (2001) contended that an academic discipline is the result of a mutually dependent interplay of the structural force of the epistemological character of disciplines that conditions culture, and the capacity of individuals and groups as agents of autonomous action. The authors pointed out (2001, p.41) that the concept of a discipline is not straightforward, since it depends not only on the existence of academic departments but also on the intellectual validity of those bodies. This point raises a question about the relationship between institutional and intellectual legitimacy (see also Manzon, 2011). Recognising that conceptual boundaries were disputed, Becher and Trowler nevertheless proceeded to group disciplines on a matrix as hard/soft and pure/applied. Education was placed in the 'soft-applied' category (p.36). However, not all observers would classify education as a discipline: some would describe it as a field which draws on other disciplines, such as sociology, psychology, philosophy 
and history (see e.g. Furlong, 2013; Furlong \& Lawn, 2011).

The above notwithstanding, it can be said that the constitutive nature of academic disciplines embraces epistemological and socio-historical dimensions. The first is concerned with intellectual substance and truth claims, and the second with the incarnation of that intellectual substance into social and political institutions. The epistemological dimension tends to display permanent, universal and necessary characteristics, while the sociological component of disciplines - given its human and cultural component - tends to exhibit changing, particular and contingent characteristics. With respect to this sociological dimension, the institutionalisation of a discipline is not limited to its formal recognition and location within the academic structure of a department or faculty. Disciplinary institutionalisation also includes the formation of scholarly societies and other forms of academic networking such as journals and conferences. It also includes the operation of 'invisible colleges', which were conceptualised by Crane (1972) as communication networks of scholars linking separate groups of collaborators within research areas. These invisible colleges, Crane suggested (pp.138-139):

help to unify areas and to provide coherence and direction to their fields. Their central figures and some of their associates are closely linked by direct ties and develop a kind of solidarity that is useful in building morale and maintaining motivation among members.

Scholarly societies and other social networks bring together communities of scholars and practitioners with common interests and identities, and further disseminate disciplinary knowledge. Clark (1987, p.233) observed that disciplinary associations in higher education have helped "tighten the hold of specialisation upon academic life, a device that would serve externally as a carrying mechanism for a discipline at large, a way of furthering specialties without regard to institutional boundaries”. Specialist journals serve as communication networks for the disciplinary communities, and give shape to the disciplines' intellectual definitions and the legitimation of disciplinary knowledge (Altbach, 1994; Coser, 1965).

Fields of study are unlike disciplines, which usually take institutional shape in university departments and faculties. According to Klein (1990), a field's presence and importance are largely determined by the field's relative visibility. This may take two forms: the overt form of interdisciplinary institutions, such as a single umbrella organisation, and the less overt forms for interdisciplinary dialogue such as study groups, symposia, conferences, publications, and institutes.

If education itself may not always be considered to be a discipline, comparative education is even less commonly considered to be one. Many analysts would agree with Lê Thành Khôi (1986, p.15), who described comparative education as "a field of study covering all the disciplines which serve to understand and explain education”. If this seems a somewhat loose description, that is because indeed the field is loose in its conceptual apparatus (Cook, Hite \& Epstein, 2004). Such looseness is manifested in the programmes of conferences organised by professional societies of comparative education and in the contents of journals and books published under the label of comparative education. As Epstein observed, comparative education, being an interdisciplinary field, is interstitial (Epstein, 1981, p.270). In this vein, the observations above reaffirm the importance of scholarly networks, such as the comparative education societies, in playing a pivotal role in the 
development and visibility of the field. In this vein, Cowen’s (1990, p.322) observation is apposite:

[The] lack of clarity over what is the epistemological core and institutional centre of comparative education means that the networks of connection between the bits and pieces of comparative education take on extra importance. Changes in networks (of new centres, journals and societies) are one measure of what comparative education is, and one indication of the definition, demand, and supply of comparative education on a world basis.

Yet while some commentators see looseness as a negative label, others view it positively. The field, they point out, accommodates diversity and provides an arena in which scholars of multiple disciplinary and practical backgrounds convene to interact and advance understanding in their chosen domains (Brock \& Alexiadou, 2013; Crossley \& Watson, 2011). Moreover, like many other facets of life, the nature of academic enquiry is changing much more rapidly in the contemporary era than in earlier decades. Furlong and Lawn (2011) considered many of the developments problematic, remarking for example that in the UK "the disciplines of education have fared badly in the last 20 years", and that in the face of government-led neo-liberal ideologies "only those institutions that have access to alternative funds ... have had any significant opportunities to maintain a degree of independence in terms of the courses they offer and in the appointment of disciplinary-based staff” (p.7). In this situation, they asserted: "Critical mass appears to be replaced by micro-communities; common disciplinary work and accumulated insight seems either unknown or impossible; skill is replaced by willingness or audit, and intellectual engagement with requisite publication” (p.4). Yet even Furlong and Lawn agreed that aspects of these patterns could be creative.

While continuing to refer to academic tribes and territories in the titles of his writing, Trowler (2011; also Trowler, Saunders \& Bamber, 2012) recognised the value of alternative metaphors and the fact that other forces may be even more powerful than knowledge structures for shaping academic practices. The earlier framework (Becher \& Trowler, 2001) took an essentialist stance in assuming almost one-to-one correspondence between epistemological factors and academic cultural practices (e.g. institutionalisation in universities and as scholarly societies). Later work recognised that this description was too simplistic. It has shown a need for other theoretical frameworks to elucidate the dynamic nature of academic practices and account for the forces in play.

\section{Dynamics of Intellectual Fields}

The interaction between epistemological and sociological factors in disciplinary change can be examined with the aid of Bourdieu's theoretical framework on intellectual fields (Bourdieu, 1969, 1975, 1977). It helps to explain the complex and dynamic processes by which social factors - structure and agency - interact with knowledge and its sociological structures.

Bourdieu (1969, p.89) described the intellectual field as "like a magnetic field, made up of a system of power lines". The constituting agents or systems of agents, he added, may be described as "so many forces which by their existence, opposition or combination”, determine the specific structure of the intellectual field at a given moment in time. The field is thus dynamically constructed by the interactions of occupants within a 
"system of positions and oppositions” (p.109). Structured by hierarchically ordered positions, the intellectual field is also governed by the dynamic law of the quest for distinction (Bourdieu, 1984, p.10). Thus intellectual interests and products - theories, methods and concepts - that appear to be disinterested contributions to knowledge can also be viewed as political strategies by agents to establish, restore, reinforce, protect or reverse structures of relations of symbolic domination. Actors compete with each other for credit in terms of the socially recognised capacity to speak and act legitimately in the production of scientific goods and the consequent command over resources for the production of more scientific goods (Lenoir, 1993, pp.76-77). Thus, in the intellectual field the political struggle to dominate resources and gain recognition is inseparable from the struggle to legitimate cognitive power to define the domains of the intellectual field (Bourdieu, 1975). This critique of intellectual practices and institutions views them as struggles for symbolic power - the capacity to name, categorise, and define legitimate forms of knowledge production (Delanty, 2001). The law of the search for distinction suggests that conflict between intellectuals will be especially intense for those holding neighbouring positions in the field (Bourdieu, 1984, p.30).

Bourdieu's field theory offers a conceptual lens to elucidate the dynamic processes involved in disciplinary or field construction. It illuminates the processes involved when emerging disciplines endeavour to distinguish themselves from amateur or lay explanations of the reality studied, as well as from older, neighbouring disciplines. It also complements Kuhn's (1962, pp.145-146) theory on scientific revolutions. This theory claims that the confirmation of a new paradigm - 'revolutionary science' - over an existing one - 'normal science' - occurs as a result of a process of natural selection from among rival pre-paradigmatic schools competing for allegiance of the scientific community. Once a paradigm shift occurs, the new paradigm transforms a group into a profession or, at least, a discipline or field of study. This leads to the formation of specialist journals, professional societies and a claim for legitimacy in academic institutions. Specialist publications are intended for professional colleagues who share knowledge of the accepted paradigm, even though some may be potential rivals.

The present paper employs Bourdieu's theory of the intellectual field to argue that the institutionalisation of comparative education into different professional societies is not simply an outcome of intellectual pursuits. Rather, it is partly a result of the complex interplay between macro- and meso-structural conditions and micro-political interests on the part of its practitioners who attempt to preserve and increase the field's visibility and their positions within it. The paper focuses mainly on the role of human agency and the quest for distinction as motors of dynamism for the field of comparative education.

\section{Units for Analysis and Comparison}

The field of comparative education is dominated by geographic descriptors. When countries are taken as the units for analysis, in most cases the boundaries can be taken as clearly defined. However, other geographic units, including world regions, may be less clear. This is evident in a focus for the present paper on Asia and the Pacific as much as other world regions. Asia includes most of Russia and most of Turkey, but those countries also include territories in Europe. Asia also includes many Arab states which, rather than identifying with Asia, 
commonly describe themselves as part of a separate region including North Africa. And while the Pacific is commonly taken to embrace Australia, New Zealand and the small states of the Melanesia, Polynesia and Micronesia, the Pacific Ocean also borders on North and South America. Thus an initial conceptual challenge for the present paper concerns the geographic boundaries of its subject matter.

From another angle, the paper takes professional societies as the unit for analysis. The societies may be easy to define insofar as they have constitutions, office bearers and members; but some societies have weak records of membership, and they sometimes co-host events with universities and other institutions in ways that blur roles and responsibilities. Moreover, some societies are defined by language and subject focus rather than by geography. Thus the Association Francophone d'Éducation Comparée (AFEC) serves speakers of French wherever they are, including in Asia and the Pacific; and the Nederlandstalig Genootschap voor Vergelijkende Studie van Opvoeding en Onderwijs (NGVO) similarly serves speakers of Dutch wherever they are. On another dimension, the International Society for Comparative Adult Education (ISCAE) serves specialists of adult education wherever they are, and a similar remark applies to the International Society for Comparative Physical Education and Sport (ISCPES).

With such factors in mind, for the present paper it has been necessary to make decisions on what should and should not be included in the focus, recognising that those decisions may not be undisputed. Table 1 lists the professional societies on which the paper focuses. It addresses parts of the world that are more likely to identify themselves culturally with Asia and the Pacific than with, say, the Arab states, North America, or South America. It also excludes the language-based associations and the global subject-based associations.

Table 1: Comparative Education Societies in Asia and the Pacific

\begin{tabular}{|l|c|c|}
\hline \multicolumn{1}{|c|}{ Name of society } & $\begin{array}{c}\text { Year } \\
\text { founded }\end{array}$ & $\begin{array}{c}\text { Member of } \\
\text { WCCES? }\end{array}$ \\
\hline Japan Comparative Education Society (JCES) & 1965 & Yes \\
Korean Comparative Education Society (KCES) & 1968 & Yes \\
Australian and New Zealand Comparative and International Education Society (ANZCIES) & 1973 & Yes \\
Chinese Taipei Comparative Education Society (CTCES) & 1974 & Yes \\
China Comparative Education Society (CCES) & 1979 & Yes \\
Comparative Education Society of India (CESI) & 1979 & Yes \\
Comparative Education Society of Hong Kong (CESHK) & 1989 & Yes \\
Comparative Education Society of Asia (CESA) & 1995 & Yes \\
Comparative Education Society of the Philippines (CESP) & 2001 & Yes \\
Council on Comparative Education of Kazakhstan (CCEK) & 2005 & Yes \\
Thailand Comparative and International Education Society (TCIES) & 2005 & No \\
Indian Ocean Comparative Education Society (IOCES) & 2011 & Yes \\
\hline
\end{tabular}

Note: This table presents data as of November 2013. Some societies had different names at earlier points in time.

The societies listed in Table 1 are presented in order of their year of establishment. The Japan Comparative Education Society (JCES) and the Korean Comparative Education Society (KCES) are among the oldest comparative education societies in the world, and were both founding members of the WCCES in 1970 (Ninomiya, 2007; Lee \& Kwon, 2007). In contrast, four of the 12 societies listed were established during the 
present century and thus are relatively young. This is both a reflection of and a stimulus for international growth of the field.

A second feature of the societies listed concerns their geographic remit. Most are national societies serving such countries as China, India and the Republic of Korea. Alongside them are sub-national bodies such as the Comparative Education Society of Hong Kong (CESHK) and regional bodies which serve groups of countries. The regional bodies are the Australian and New Zealand Comparative and International Education Society (ANZCIES), the Comparative Education Society of Asia (CESA), and the Indian Ocean Comparative Education Society (IOCES). However, none of these societies restricts membership to nationals or even residents of the geographic areas indicated in the names of the societies. They are glad to welcome members from other parts of the world who have an interest in the geographic areas served by the societies. With such heterogeneous membership, it would be difficult to draw definite cultural boundaries taking the comparative education society as a unit for analysis. ${ }^{1}$

A third feature of the table concerns the place of international education alongside comparative education. Wilson (1994) described this pair of fields as Siamese twins, seeing comparative education as more academic and international education as more applied, particularly when professionals from one country work in another country on education projects devised by multilateral agencies and similar bodies. Along the same lines, Rust (2002) described comparative education as an analytic and scientific activity, and international education as being more related to cooperation, cross-national understanding and exchange. Among the 12 societies listed, two include International in their names. However, the fact that International is absent from the names of the others does not necessarily mean that it is absent in reality. Reflecting the loose boundaries of comparative education, much work conducted under the name of comparative education might be better described as international education or even foreign education - i.e. study of features in education in countries other than the ones in which the person conducting the study is based. Names and name changes reflect wider intellectual shifts as well as pragmatic matters of funding and institutional politics (Manzon \& Bray, 2007a, p.350).

A fourth feature of the table concerns WCCES membership. Most societies listed were members, but the Thailand Comparative and International Education Society (TCIES) was not. The WCCES had signalled that it would welcome an application for membership (Bray, 2007, p.85). In informal communications the TCIES leadership expressed intention to make an application (Siribanpitak, 2013), but at the time of writing it had not done so.

A further remark about the table echoes methodological themes in other contexts. When countries are taken as the units for analysis in the field of comparative education, they are commonly allocated equal space, e.g. occupying one line each in numerical tables, despite their great diversity in population size, geographic area, and economic wealth. Similarly, Table 1 allocates equal space to the comparative education societies even though they differ significantly in membership size, geographic coverage and annual income. The Japan Comparative Education Society (JCES) had over 1,000 members and was thriving, while the Comparative

\footnotetext{
${ }^{1}$ We are grateful to Shoko Yamada for sharing this observation during an informal conversation on 24 June 2013 during the $15^{\text {th }}$ World Congress of Comparative Education Societies in Buenos Aires.
} 
Education Society of the Philippines (CESP) had been dormant for some years until its revitalisation in 2013. Variations in size chiefly reflected the enthusiasm with which the societies' leaders recruited members rather than the population sizes of the geographic areas served by the societies. Underlying the success of attracting members was also the status of education research in general, and of comparative education research in particular, at universities and teacher training colleges. Comparative education courses in graduate programmes provide a potential source of recruits for professional societies. It is probably due to these factors that there is no professional society of comparative education in Singapore despite the presence and work of several comparative education scholars in its tertiary institutions.

Juxtaposition of national, sub-national and regional societies also shows overlap in geographic coverage. ANZCIES, which is here described as a regional body, is constitutionally defined as serving just two countries but desires to reach out to neighbours in the South Pacific (McLaughlin, 2013). CESA serves parts of the region which have national societies, though a major consideration at the time of establishment was service to scholars in countries which did not have national societies (Mochida, 2007, p.309). The name of the IOCES stressed sea water (i.e. the Indian Ocean) rather than land, but at least some of its officers viewed the society as serving all countries with borders on or surrounded by the Indian Ocean, i.e. ranging from Kenya in the western perimeter to Thailand in the east, and from Australia in the south to Bangladesh in the north (Karunaratne, 2013).

Taking these observations together, the methodological point may be restated that units for comparison that at first sight may seem clear can transpire on closer inspection to have ambiguities and complexities. This observation in the context of the present paper has corollaries in other domains for comparative analysis of education (Bray, Adamson \& Mason, 2014).

\section{The WCCES as Facilitator, Legitimator and Gate-keeper}

The WCCES Statutes indicate that the aims of the Council include to "facilitate co-operation between comparative educationists of different countries and regions, and foster the establishment of professional associations and groups of comparative educationists” (WCCES, 1996, Article 2.3). The Council has taken pride in its expansion from five member societies in 1970 to 39 societies in 2013, albeit with some fluctuation due to the demise of a few societies. The expansion reflects a combination of outreach from the WCCES and self-initiated application from associations and groups of comparative educationists. The WCCES and its Standing Committees seek to reach out to groups of comparativists in the 'periphery' regions. This is achieved through nurturing and facilitation of new societies and supporting them in developing a presence in the WCCES as member societies, by widening the geographic representation of Standing Committee members, and by extending conference travel subsidies to needy scholars. This thrust was embodied in the theme of its 2013 World Congress in Buenos Aires, namely "New Times, New Voices”.

Within the WCCES, during the period covered by this paper (i.e. 2007 to 2013) applications for membership have been facilitated by the Admissions and New Societies Standing Committee. This body not only manages receipt of applications but also prospects for new applications. The Standing Committee advises applicants of the requirements, and prepares documentation for decision-making by the WCCES Executive 
Committee. It informs potential applicants of the benefits of membership, among which the most obvious is professional collegiality and participation in a body with a global vision. On their side, potential applicants commonly value the legitimating dimension of WCCES membership. Indeed for at least two national bodies in Spain and Cuba - the objective of securing representation in the world body was a motivation for groups of scholars to organise themselves as societies (Manzon \& Bray, 2007a, p.343).

At the same time, the WCCES has to some extent been a gate-keeper. The By-laws (WCCES, 2005, section 2.3.iv) state that societies or groups of comparative educators desiring to become members must:

- be duly constituted to pursue comparative education;

- agree to the objectives of the WCCES as described in the Statutes, which includes adherence to the ideals of the United Nations and of UNESCO;

- express willingness to fulfil the obligations of member societies as specified in the Statutes, including nomination of representatives and payment of membership dues; and

- not infringe the interests of any existing members.

This last clause has usually been taken in a geographic sense, i.e. if a WCCES member society already exists to serve a specific location, then the question of admission of a new group should at least be discussed with care to determine the nature of overlap. The above criteria for membership, however, do not accord the WCCES a gate-keeping role with respect to epistemological rigor. The WCCES has no procedures for evaluating the quality of the intellectual work of applicant societies; nor does it have any procedures to monitor the activities of existing member societies other than demanding regular payment of membership dues.

Experiences have revealed complexities in the ways that the WCCES determines matters of geographic overlap when new societies apply for admission. At various times WCCES personnel have drawn maps with shaded jurisdictions deemed to be served by member societies. Maps with national boundaries are open to political disputes, illustrated by divergence in views on sovereignty and self-determination in Greater China (Hong Kong, Macao, Mainland China and Taiwan). Even more problematic is the drawing of regional boundaries, e.g. for CESA, the IOCES, and counterparts in the Arabian Gulf, Europe and Southern Africa. Further, as noted above, the language-based societies for speakers of French and of Dutch are not constrained by geography at all.

Nevertheless, ways in which the gate-keeping role has operated are evident not only when applications have been approved but also when potential applicants have been discouraged. Among the latter is a group from India who desired to establish a society in the mid- and late 2000s. Part of the context was that the Comparative Education Society of India (CESI) had been established in 1979 and admitted to the WCCES in 1980. The 2007 histories book noted (Manzon \& Bray, 2007b, p.324) that CESI had become "rather inactive" after the late 1980s. One reviewer of that book (Singh, 2009, p.78) was more forthright in describing CESI as “dysfunctional”. In 2006, members of the WCCES Executive Committee had been informed that CESI was being revived, and on that basis WCCES officers discouraged another group which would have constituted 
itself and applied for membership. CESI did not immediately revive, and the other group was frustrated. This formed part of the momentum for an Interdisciplinary Indian Ocean Comparative Education Forum (IIOCEF) and the Indian Ocean Comparative Education Society (IOCES) which were created during the period (WCCES Admissions and New Societies Standing Committee, 2010, pp.1-2). Ultimately CESI did revive, holding significant annual conferences and engaging in other activities from 2010 onwards. In this respect, perhaps the WCCES objectives had been well placed. The IIOCEF was incorporated within the IOCES; and the IOCES held its initial conferences in Sri Lanka, Maldives and Thailand, thereby avoiding the Indian geographic space.

A parallel pattern concerned the Comparative Education Society of the Philippines (CESP), which had been formed in 2001 and was admitted to the WCCES in 2002 (Manzon \& Bray, 2007b, p.330). This society also lapsed into inactivity, in part because its principal office-bearer was based in the USA rather than the Philippines. Again the WCCES Executive Committee heard frustrations that the CESP was occupying the institutional space but was inactive. In early 2013, an active Filipino group within CESA prepared to establish a (new) Philippine comparative education society unaware of the existing one recognised by the WCCES as a member society. Through the mediation and encouragement from the WCCES Executive Committee, and particularly the Chair of the Admissions and New Societies Standing Committee, the CESP was successfully revived, pulling together scholars from three different Philippine universities. In October 2013, the revitalised CESP held its first meeting and elected its office bearers. These developments matched patterns in some other WCCES member societies: as the foundational generation of leaders wanes, a new generation seeks to revitalise the society. In this process, some tensions may arise, as will be noted in the next section.

Like many other global bodies, the WCCES faces challenges arising from language - on which the Statutes and By-laws are silent. In the Council's early years, much communication was conducted in French as well as English, and the WCCES logo, which dates from the 1989 hosting of a Congress in Montreal, is bilingual in French and English. In recent decades, however, almost all official WCCES business has been conducted in English. Exceptionally, the spoken parts of the WCCES Executive Committee meetings in Buenos Aires during the $15^{\text {th }}$ World Congress (June 2013) were conducted in both English and Spanish with simultaneous translation in both languages. This facilitated the participation of many Latin American representatives in particular, though all documentation remained in English. While the use of English is convenient for some actors, it marginalises others. The dominance of English in the WCCES affairs is part of a wider pattern that has critics as well as advocates (see e.g. Macedo, Gounari \& Dendrinos, 2003; Tietze \& Dick, 2013).

A final comment is pertinent to the 'quest for distinction' identified by Bourdieu (1984), which suggests that conflicts between groups of intellectuals will be especially intense for those holding neighbouring positions in the field. The above examples citing the creation of new societies whose geographic boundaries overlap with existing albeit (apparently) dormant societies have demonstrated to some extent how the search for distinction accounts for some of the dynamics in the field. In Asia, the cases of CESI, IOCES, CESP, and an active Filipino group within CESA, resonate with histories elsewhere of society formation. In Europe, for example, various 
national societies have been formed by splintering from the regional Comparative Education Society in Europe (CESE). These events have reflected the homology between political fields and intellectual fields (Manzon, 2011).

\section{Activities of Comparative Education Societies}

Around the world, the most obvious activities of comparative education societies are the convening of conferences and the publication of journals and other materials such as conference proceedings. These activities help to disseminate disciplinary knowledge, raise awareness, and attract new members. They also legitimise the institutional existence of the societies, and help to maintain or expand their intellectual territories. The activities are here considered in turn with reference to the societies on which this paper focuses. The frequency of the conferences is an indicator of intensity of activity, their locations reflect dimensions of partnership, and their official themes are an indicator of content. Similar remarks about frequency and content apply to the publications.

\section{Conferences sponsored by the societies}

Table 2 presents data on the conferences held during the period 2007-2013. Some societies held annual conferences while other societies held biennial or irregular events. Variations in the frequency partly reflected the goals of the societies but also reflected their robustness. As noted, CESI had been dormant during the 1990s but was revived during the late 2000s, and in 2010 resumed a tradition of annual conferences. CESA aspired to biennial conferences, but slipped in its calendar and after 2007 held its next conference in 2010 rather than 2009. The CESP was dormant throughout the period, and held no conferences at all.

Table 2: Conferences of Comparative Education Societies in Asia and the Pacific, 2007-2013

\begin{tabular}{|c|c|c|c|}
\hline Society & Year & Location & Theme \\
\hline JCES [Japan] & $\begin{array}{l}2007 \\
2008 \\
2009 \\
2010 \\
2011 \\
2012 \\
2013\end{array}$ & $\begin{array}{l}\text { University of Tsukuba } \\
\text { Tohoku University } \\
\text { Tokyo Gakugei University } \\
\text { Kobe University } \\
\text { Waseda University } \\
\text { Kyushu University } \\
\text { Sophia University }\end{array}$ & $\begin{array}{l}\text { The society has not set overarching themes. Instead it has } \\
\text { provided a forum for colleagues to meet with multiple interests. } \\
\text { For example, members joining the } 2013 \text { conference were asked } \\
\text { to identify their contributions according to } 10 \text { geographical } \\
\text { areas and/or } 24 \text { themes (panels). }\end{array}$ \\
\hline KCES [Korea] & $\begin{array}{l}2007 \\
2008 \\
2009 \\
2010 \\
2011 \\
2012 \\
2013\end{array}$ & $\begin{array}{l}\text { Jeju National University } \\
\text { Kangwon National University; } \\
\text { Seoul National University } \\
\text { Kyungpook National University } \\
\text { Ewha Womans University } \\
\text { Korea National University of } \\
\text { Education; Hanyang University } \\
\text { Chungnam National University; } \\
\text { Gwangju National University of } \\
\text { Education } \\
\text { Gyeongin National University of } \\
\text { Education } \\
\text { Korea National University of } \\
\text { Education }\end{array}$ & $\begin{array}{l}\text { The society has not set conference themes. Instead it has } \\
\text { organised periodic conferences for colleagues to share their } \\
\text { academic interests. }\end{array}$ \\
\hline ANZCIES [Australia & 2007 & University of Auckland, New & co-operation through education \\
\hline
\end{tabular}




\begin{tabular}{|c|c|c|c|}
\hline \& New Zealand] & $\begin{array}{l}2008 \\
2009 \\
2010 \\
2011 \\
2012 \\
2013\end{array}$ & $\begin{array}{l}\text { Zealand } \\
\text { Curtin University, Australia } \\
\text { University of New England, } \\
\text { Australia } \\
\text { Royal Melbourne Institute of } \\
\text { Technology, Australia } \\
\text { University of Sydney, Australia } \\
\text { University of Canterbury, New } \\
\text { Zealand } \\
\text { University of Newcastle, } \\
\text { Australia }\end{array}$ & $\begin{array}{l}\text { Meeting of comparative minds: Education in all its forms } \\
\text { Entering the age of an educational renaissance: Ideas for unity } \\
\text { of purpose or further discord? } \\
\text { Bordering and new possibilities in education and society } \\
\text { Education and belonging } \\
\text { Reforming education: Dreams and realities } \\
\text { Learning and living in the world and with the world: New } \\
\text { possibilities for space, place, and time in comparative and } \\
\text { international education }\end{array}$ \\
\hline CTCES [Taipei] & $\begin{array}{l}2007 \\
2008 \\
2009 \\
2010 \\
2011 \\
2012 \\
2013\end{array}$ & $\begin{array}{l}\text { National University of Tainan, } \\
\text { Taiwan } \\
\text { National Chung Cheng } \\
\text { University, Taipei } \\
\text { National Taiwan Normal } \\
\text { University, Taipei } \\
\text { National Chung Cheng } \\
\text { University, Taipei } \\
\text { The Garden Villa, Kaohsiung } \\
\text { National Taiwan Normal } \\
\text { University, Taipei } \\
\text { National Taiwan Normal } \\
\text { University, Taipei }\end{array}$ & $\begin{array}{l}\text { The development and governance of higher education: } \\
\text { Comparative perspective } \\
\text { Higher education quality assurance } \\
\text { Dialogue between educational research and educational policies } \\
\text { Cross-border education: Theory and practice } \\
\text { International comparison of teacher quality } \\
\text { Education vision } 2020 \text { international conference } \\
\text { Internal transformation: Creating active agents in teaching and } \\
\text { learning }\end{array}$ \\
\hline CCES [China] & $\begin{array}{l}2008 \\
2010 \\
2012\end{array}$ & $\begin{array}{l}\text { Wenzhou University } \\
\text { Zhejiang University } \\
\text { Northeast Normal University }\end{array}$ & $\begin{array}{l}\text { Educational reforms in China and comparative education } \\
\text { research } \\
\text { Professor Wang Chengxu's educational thought } \\
\text { Educational reforms and innovation, and contemporary } \\
\text { responsibility of comparative education }\end{array}$ \\
\hline CESI [India] & $\begin{array}{l}2010 \\
2011 \\
2012 \\
2013\end{array}$ & $\begin{array}{l}\text { Jawaharlal Nehru University } \\
\text { University of Hyderabad } \\
\text { University of Jammu } \\
\text { University of Calcutta } \\
\end{array}$ & $\begin{array}{l}\text { Globalisation, education change and reforms: Comparative } \\
\text { perspective } \\
\text { Rethinking education policy } \\
\text { Education for a changing world } \\
\text { Education, diversity and democracy }\end{array}$ \\
\hline CESHK [Hong Kong] & \begin{tabular}{l|}
$2007^{*}$ \\
2008 \\
2009 \\
2010 \\
2011 \\
2012 \\
2013 \\
\end{tabular} & $\begin{array}{l}\text { University of Hong Kong } \\
\text { Hong Kong Institute of Education } \\
\text { University of Macau } \\
\text { South China Normal University, } \\
\text { China } \\
\text { Hong Kong Institute of Education } \\
\text { University of Hong Kong } \\
\text { Chinese University of Hong Kong }\end{array}$ & $\begin{array}{l}\text { Learning from each other in an Asian century } \\
\text { Comparative visions, comparative missions } \\
\text { Post-colonial education development } \\
\text { Globalization within regionalization: Identity, understanding } \\
\text { and interactions } \\
\text { Comparative education, sustainable development and social } \\
\text { justice } \\
\text { Exploring the value and values of comparative education } \\
\text { Educational reform and social change: East-West dialogue }\end{array}$ \\
\hline CESA [Asia] & $\begin{array}{l}2007 * \\
2010 \\
2012\end{array}$ & $\begin{array}{l}\text { University of Hong Kong } \\
\text { Gwangju National University of } \\
\text { Education, Republic of Korea } \\
\text { Chulalongkorn University, } \\
\text { Thailand }\end{array}$ & $\begin{array}{l}\text { Learning from each other in an Asian century } \\
\text { Diversity, co-existence and challenge of multicultural } \\
\text { education in Asian countries } \\
\text { Education at the dawn of the new decade: When the quality } \\
\text { and sustainability movements converge }\end{array}$ \\
\hline CESP [Philippines] & \multicolumn{3}{|c|}{ No conference activity during this period } \\
\hline CCEK [Kazakhstan] & 2008 & $\begin{array}{l}\text { Academy of Pedagogical } \\
\text { Sciences, Astana } \\
\text { Academy of Pedagogical } \\
\text { Sciences, Astana }\end{array}$ & $\begin{array}{l}\text { Comparative education } \\
\text { Comparative education }\end{array}$ \\
\hline TCIES [Thailand] & \multicolumn{3}{|c|}{2012 and 2013: co-sponsored 7 seminars/lectures in Chulalongkorn University } \\
\hline IOCES [Indian Ocean] & $\begin{array}{l}2010 \\
2011 \\
2013\end{array}$ & $\begin{array}{l}\text { Peradeniya University, Sri Lanka } \\
\text { Villa College, Male, Maldives } \\
\text { Khon Kaen University, Thailand }\end{array}$ & $\begin{array}{l}\text { Comparing education shores: The Indian Ocean case } \\
\text { Globalization of education: Convergence towards a world } \\
\text { culture of schooling } \\
\text { Challenging education for future change }\end{array}$ \\
\hline
\end{tabular}

* Jointly-hosted CESHK and CESA event 
The table also presents data on locations. As one might expect, the conferences of the Japanese society were held in various locations of Japan, those of the Korean society in various locations of the Republic of Korea, etc.. However, the Comparative Education Society of Hong Kong (CESHK) held two conferences in neighbouring locations, i.e. Macao and Guangzhou (Mainland China) rather than in Hong Kong itself. On the CESHK side this showed a willingness to reach out beyond geographic and political borders to gain new partnerships; and it seemed that the China Comparative Education Society (CCES) had no objection.

More to be expected was diversity in the locations of conferences held by bodies with an explicit focus on more than one country. Thus, during the period the dual nature of ANZCIES was evident in its holding of two conferences in New Zealand and five in Australia (which has a much larger population and area). CESA held one joint conference with the CESHK in Hong Kong, and the other two conferences in Thailand and the Republic of Korea. As noted above, Thailand was also the location of one of the three conferences of the IOCES, the other two being more obviously Indian Ocean countries namely Sri Lanka and Maldives.

A different dimension of location concerns the institutional hosts for the conferences. In the USA, the CIES commonly holds its conferences in hotels. This reflects the size of the events, which usually considerably exceeds 1,000 people. In the Asia-Pacific conferences, university venues have been much more prominent. This has been possible because the events have been limited in size, and it has given them a more academic flavour. In some cases, moreover, the institutions have provided sponsorship. Thus, a major reason why the 2013 IOCES conference was held in Thailand was that Khon Kaen University welcomed the event as part of the its $50^{\text {th }}$ anniversary celebrations.

Another element of Table 2 concerns the conference themes. The two oldest societies, JCES and KCES, had no overarching themes. Nevertheless, the JCES does exercise subtle forms of legitimation and gate-keeping in the themes accepted for presentation. Takayama (2013) pointed out epistemological tensions and divergences between the older generation of Japanese scholars and the new generations of scholars, some of whom were trained in North America or Europe. He observed that while the dominant paradigm of comparative education research since the foundational years had been area studies, which are mainly descriptive and require deep knowledge of local contexts and languages, foreign-trained new generations of scholars are promoting a thematic and eclectic paradigm for comparative research. This has been viewed by some senior scholars as ‘cheap’ comparative education research. This pattern echoes Kuhn's and Bourdieu's observations about paradigm wars in the struggle for intellectual and institutional legitimacy.

The other societies did set overarching themes, but no society insisted that all presenters adhere to the themes - and in any case most themes were broad and accommodating. Nevertheless, some variation in the types of themes is worth noting. Some had short titles, such as the 2011 ANZCIES theme 'Education and belonging', while others were long, such as the 2013 ANZCIES theme 'Learning and living in the world and with the world: New possibilities for space, place, and time in comparative and international education'. Many had conceptual components, such as social justice, globalisation and educational renaissance. One honoured the work of a named scholar, Professor Wang Chengxu who had reached the age of 100. Only three mentioned geographic focus, in two cases that being Asia, and in the third case the shores of the Indian Ocean. Two 
mentioned levels of education, namely the 2007 and 2008 Chinese Taipei society's focus on higher education. Some themes also reflected underlying (multi-)cultural and social dynamics in the societies' membership and wider context. For example, ANZCIES exhibited some continuity in discourse with such terms as unity, bordering, and belonging.

The influence of the WCCES was also evident. In 2010, members of WCCES constituent societies convened in Istanbul, Turkey, for the $14^{\text {th }}$ triennial World Congress of Comparative Education Societies on the theme 'Bordering, Re-bordering and New Possibilities in Education and Society'. The 2010 ANZCIES theme was an explicit preparation, and the 2010 CTCES theme was allied.

\section{Publications and other forms of dissemination}

Publications in the forms of journals and conference proceedings have traditionally been the principal form of dissemination for comparative education societies around the world. As noted above, journals serve as a communication network for the field and give shape to disciplinary definitions and intellectual legitimacy.

Table 3 presents information on the societies' official publications between 2007 and 2013. The table refers to five journals, a pair of conference proceedings, and a newsletter. In addition, individuals and groups published books, articles and chapters that emanated from or were connected with societies' conferences. The volumes of the Council on Comparative Education of Kazakhstan (CCEK) illustrate the point, since the identity of the CCEK and its hosting Academy of Pedagogy overlapped.

Table 3: Publications of Comparative Education Societies in Asia and the Pacific, 2007-2013

\begin{tabular}{|c|c|c|}
\hline Society & Journals, Newsletters and Conference Proceedings & Website \\
\hline JCES [Japan] & $\begin{array}{l}\text { The journal Comparative Education, founded in 1974, moved to two issues per year in } \\
\text { 2006. Until 2009, all articles were in Japanese; but from that year a few articles were in } \\
\text { English. In addition, some Japanese-language articles had English-language abstracts. }\end{array}$ & Yes \\
\hline KCES [Korea] & $\begin{array}{l}\text { The Korean Journal of Comparative Education was founded in 1971. It published only } \\
\text { one issue a year 1971-1997, expanding to two issues 1998-2003, three issues } 2004 \text { and } \\
\text { 2005, four issues 2006-2009, five issues 2010-2012, and six issues 2013. The } \\
\text { dominant language was Korean, but other languages were permitted. Between } 1971 \\
\text { and 2012, in the mainly-Korean-language issues, } 35 \text { papers were published in English, } \\
\text { three in Japanese, two in Chinese, and one in French. In addition, each year in } \\
\text { 2010-2012 a full issue was English-only (containing } 22 \text { papers in the three issues). } \\
\text { Two English-only issues were planned for 2013. }\end{array}$ & Yes \\
\hline $\begin{array}{l}\text { ANZCIES } \\
\text { [Australia \& } \\
\text { New Zealand] }\end{array}$ & $\begin{array}{l}\text { ANZCIES sponsors the International Education Journal: Comparative Perspectives. } \\
\text { All content is in English. The journal was launched by a private publisher in 1999. It was } \\
\text { taken over by ANZCIES in 2007, and the WCCES granted some financial support in } \\
\text { 2008. Seven issues (all in English) were produced between } 2007 \text { and } 2012 \text {. Three issues } \\
\text { were published in 2007, two in 2008, none in } 2009 \text { of 2010, two in } 2011 \text { and one in } \\
\text { 2012. A Newsletter was also published intermittently: twice in 2007, twice in 2012, and } \\
\text { once in 2013. The irregularity reflected flows in the leadership. }\end{array}$ & Yes \\
\hline $\begin{array}{l}\text { CTCES } \\
\text { [Taipei] }\end{array}$ & $\begin{array}{l}\text { The Journal of Comparative Education, founded in } 1982 \text { as a Chinese-language journal, } \\
\text { maintained two issues per year. Over the decades, English became more prominent. For } \\
\text { example, among the } 18 \text { articles published in the four issues in } 2011 \text { and 2012, nine were } \\
\text { in English. All articles in these issues had abstracts in both English and Chinese. }\end{array}$ & Yes \\
\hline CCES [China] & $\begin{array}{l}\text { The Comparative Education Review has been published under that name since } 1992 \text { (but } \\
\text { with an ancestry dating back to 1965). From } 1992 \text { to } 2001 \text { it was published six times a } \\
\text { year, and then moved to } 12 \text { times a year. It is a Chinese-medium journal, with } \\
\text { English-language abstracts. }\end{array}$ & Yes \\
\hline
\end{tabular}




\begin{tabular}{|l|l|c|}
\hline CESI [India] & None & Yes \\
\hline $\begin{array}{l}\text { CESHK [Hong } \\
\text { Kong] }\end{array}$ & $\begin{array}{l}\text { The Comparative Education Bulletin was launched in 1998. Annual editions were } \\
\text { published 2007-2009, and then 2011-2012 [i.e. with a gap for 2010], with average of 82 } \\
\text { pages. The majority of articles (84.6\%) were in English, but some were in Chinese. In } \\
\text { 2013 the society's Annual General Meeting accepted a proposal from the President and } \\
\text { Executive Committee to change the name to the International Journal of Comparative } \\
\text { Education and Development. }\end{array}$ & Yes \\
\hline $\begin{array}{l}\text { CESA [Asia] } \\
\text { [PSilippines] }\end{array}$ & None & Yes \\
\hline $\begin{array}{l}\text { CCEK } \\
\text { [Kazakhstan] }\end{array}$ & $\begin{array}{l}\text { The CCEK contributed to a Russian-language journal for the Academy of Pedagogy of } \\
\text { Kazakhstan with two issues per annum; but that was the Academy's journal rather than } \\
\text { the CCEK's. In addition, 18 books associated with the CCEK were published by the } \\
\text { sponsoring Academy and other publishers during the period 2007-2013. }\end{array}$ & Yes \\
\hline $\begin{array}{l}\text { TCIES } \\
\text { [Thailand] }\end{array}$ & None & No \\
\hline $\begin{array}{l}\text { IOCES [Indian } \\
\text { Ocean] }\end{array}$ & Two volumes of selected papers were published, from the 2010 and 2011 conferences & Yes \\
\hline
\end{tabular}

Note: Data for 2013 apply up to November of that year.

In addition to paper publications, websites have become very important. The absence of websites in two cases again indicates lack of dynamism in these societies. In the case of the CESP, this is understandable since at the time of writing it had just been revitalised. By contrast, a few societies had well-developed websites. The WCCES website was itself refurbished in 2012, and provided a central location through which the websites of member societies could be accessed.

Turning back to the journals, Furlong and Lawn (2011, p.10) highlighted the way that "the speed of reformation, sub-disciplinary groupings, interest-based developments and utilitarian, sponsor-based work re-shapes the field [of educational studies] constantly". They added that: "Journals arrive without a past, reflecting (often creatively) new areas of work and old journals linger on, supplied by the necessity of research audit publication.” Applying this lens to the journals listed in Table 3, it may be noted that some societies had longstanding journals. Especially prominent was the CCES journal, which appeared monthly and would be described as dynamic rather than lingering on. Other journals did arrive without a past, and one launched during the period was short lived. This was the CESA journal entitled Compare: Journal of the Comparative Education Society of Asia, which produced two issues in 2006 and then ceased production. The ANZCIES International Education Journal fluctuated in activity but did maintain its existence. The JCES and CTCES journals were more steady in their production.

Linking back to the issues of language, it is also pertinent to identify the role of English alongside national languages. Thus while the JCES journal had been exclusively in Japanese until 2009, in that year articles including ones written by Japanese scholars - began to appear in English. The KCES journal went even further with publication of one or two issues per annum exclusively in English. This journal also had a history of publishing in Japanese, Chinese and French, but only rarely (Keoun, 2013). Perhaps less surprising is the role of English in the CESHK Bulletin, since English is an official language in Hong Kong alongside Chinese. However, the balance within the Bulletin heavily favoured English with only $13.4 \%$ of articles being published 
in Chinese between 2007 and 2012. The CCES journal retained its policy of publishing all articles in Chinese, but it nevertheless produced a contents page and abstracts of all articles in English.

\section{Conclusions}

This article has explored aspects of the institutionalisation of comparative education as they relate to comparative education societies in Asia and the Pacific. Employing the metaphor of academic tribes and territories to note some of the forces that shape disciplines and fields, it has noted the interplay of epistemological and sociological structures in disciplinary institutionalisation. Scholarly societies and other forms of academic networking such as journals and conferences play important roles in the construction of institutional and intellectual legitimacy. Taking the analysis a step further, the paper employed Bourdieu's theory of the intellectual field, governed by the law of distinction, as part of the explanatory framework for patterns. The institutionalisation of comparative education in professional societies and their related journals and conferences is not solely an outcome of intellectual pursuits. It also results from the complex interplay between macro and meso-structural conditions and micro-political interests on the part of its practitioners who attempt to preserve and expand the field and their positions within it. The discussion has also noted the role of human agency within the professional societies, and their quest for distinction as motors of dynamism for the field.

Starting with a description of the 12 comparative education societies in the Asia-Pacific region, which include three regional and nine national/sub-national bodies, the paper has highlighted the WCCES' roles as facilitator, legitimator and gate-keeper for the field's institutional growth. Through the formation of professional societies and their conferences and journals, the field of comparative education in the region developed during the period under consideration, albeit unevenly.

Among the explanatory factors for the uneven robustness of the societies and journals are the roles of individuals. Clear evidence is available on the impact of individual scholars (or the lack of it, resulting in dormant and non-existent societies) and their networks, communication competencies and personal drive in establishing new scholarly networks, at times even leading to the fragmentation of societies and an overlap of academic territories. Conceptualising national and regional societies as located in an intellectual field constituted by a network of power relations among other educational and/or social science-related societies, the narrative has shown that societies compete for a distinctive institutional position within national and/or regional boundaries and within the global framework of the WCCES. As Epstein (1981, p.269) remarked, “a field's tenability depends on whether the people who run a professional association can capture recognition for their specialisation”. With institutional recognition comes access to institutional resources for expanding the field (Furlong \& Lawn, 2011).

Within the global framework of the WCCES, member societies have also been motivated to seek distinctiveness from each other. Illustrations include the formation of national societies separate from regional bodies such as CESA (e.g. TCIES, and the new group of Filipino comparativists that emerged in 2013). The formation of an academic society can thus be seen as a "non-discursive move to symbolise academic 
distinctiveness and belonging to a global network" (Manzon, 2011, p.122). It is a means to legitimise the field of comparative education in a specific geographical ambit and to legitimate cognitive power to define the boundaries of the field, e.g. through agenda-setting of conference themes and review of submissions to journals. Yet some societies either had no overarching themes for their conferences or set themes that were all-embracing. This pattern indicates some limitations in the scale and impact of the intellectual energies being deployed for demarcation of the field. Nevertheless, a closer observation of the JCES has revealed that despite its seemingly broad conference themes, programme organizers exercise a subtle gate-keeping power by rejecting some conference papers due to their 'non-paradigmatic' topics. Likewise sub-tectonic tensions and divides are emerging between 'normal science' paradigms upheld by foundational leaders and 'revolutionary science' paradigms proposed by new generation scholars, echoing the propositions of Kuhn and Bourdieu.

The article has also highlighted ways in which languages mediate and filter the power to achieve intellectual legitimacy. Particularly striking is the role of English and its implications not only within the region but also in the global platform of the WCCES. Table 3 noted the existence of six journals sponsored by comparative education societies during the period 2007-2013, plus one sponsored by an associated Academy to which the comparative education council contributed. One of these journals was sponsored by the Australian and New Zealand society, and was naturally in English since that is the official language of both countries. English is also one of the official languages of Hong Kong, alongside Chinese; but it is not an official language in Japan, the Republic of Korea, Chinese Taipei, or the People’s Republic of China. The journals of societies in all these jurisdictions had English-language abstracts alongside the content in their national languages, and some published full articles and even complete issues in English. This growing trend strongly favoured English above any other non-national languages. The case of the KCES journal is especially striking. Between 1971 and 2012, 63 articles were published in a language other than Korean. Among those articles, 57 were in English while three were in Japanese, two were in Chinese and one was in French. The growing power of English shows that the tribes were finding a common medium for discourse; but that medium brought its own biases and exclusions. The fact that the societies felt a need to publish in English reflected challenges of communication through other languages. It also reflected the limited visibility, recognition and therefore cognition of power to re-define the field through languages other than English.

Another implication for the field, not only within Asia and the Pacific but also globally, derives from the divergence and/or bifurcation of institutional and intellectual legitimacies. The proliferation of comparative education societies and their respective conferences and journals, while signalling institutional growth, may be counterproductive if the academic territory (intellectual substance) is not well defined and the academic tribe inhabiting the territory is not well versed in the substance of the field and its ancestry. Elaborating on the fact that conference themes may be very broad and the gate-keeping for conferences and publications as well as society formation may be loose, some communities may lack sufficient scholarly initiation and apprenticeship into the theories, methodologies and histories of comparative education.

Further concerns relate to the sustainability of scholarly networks, especially when much depends on the agency of individual scholars and their energies and personal connections. In the vocabulary of Becher and 
Trowler (2001), the academic practices of specific tribes are shaped by the academic territories that they occupy. Transposing these concepts to comparative education, the looseness in tribal practices mirrors a looseness in the epistemological features of its territory as a field of study. More deeply, the fault might not be with the epistemological structure but with the intellectual literacy of the socio-historical inhabitants of the field. The onus therefore lies on the key actors who have institutional and intellectual power in the field, whether nationally, regionally or globally, to find ways to ensure that institutional growth is not at the expense of intellectual solidity. In this respect, it might be valuable for all societies - new and old, large and small - and the WCCES to have a permanent 'educative' component on comparative education history, theory and methodology in their conferences and other activities, rather than having a variable agenda catering only to 'hot' topics. In the absence of such a core, the move to attract wider audiences may become counterproductive and result in a further dilution of the field's identity and intellectual legitimacy. Such patterns may in the long run erode the impact of the informed and loyal community, and undermine the initiation of new generations of scholars to lead the field into the future. In the final analysis, distinction in the field is carved out not only by global institutional presence but also by solid intellectual substance.

\section{References}

Altbach, Philip H. (1994): 'International Knowledge Networks', in Husén, Torsten \& Postlethwaite, T. Neville (eds.), The International Encylopedia of Education, $2^{\text {nd }}$ edition, Oxford: Pergamon Press, pp.2993-2998.

Becher, Tony (1989): Academic Tribes and Territories: Intellectual Enquiry and the Cultures of Disciplines. Buckingham: The Society for Research into Higher Education \& Open University Press.

Becher, Tony \& Trowler, Paul R. (2001): Academic Tribes and Territories: Intellectual Enquiry and the Culture of Disciplines. $2^{\text {nd }}$ edition. Buckingham: The Society for Research into Higher Education \& Open University Press.

Bourdieu, Pierre (1969): 'Intellectual Field and Creative Project’ (Trans. S. France). Social Science Information, 8 (2), 89-119.

Bourdieu, Pierre (1975): 'The Specificity of the Scientific Field and the Social Conditions of the Progress of Reason'. Social Science Information, 14, 19-47.

Bourdieu, Pierre (1977): Outline of a Theory of Practice (Trans. R. Nice). Cambridge: Cambridge University Press.

Bourdieu, Pierre (1984): 'The Market of Symbolic Goods', in Bourdieu, Pierre, The Field of Cultural Production: Essays on Art and Literature. New York: Columbia University Press, pp.1-34.

Bray, Mark (2007): 'Expanding the Coverage and Hearing More Voices: 2004-2007’, in Masemann, Vandra; Bray, Mark \& Manzon, Maria (eds.), Common Interests, Uncommon Goals: Histories of the World Council of Comparative Education Societies and its Members. Hong Kong: Comparative Education Research Centre, The University of Hong Kong, and Dordrecht: Springer, pp.83-93.

Bray, Mark; Adamson, Bob \& Mason, Mark (eds.) (2014): Comparative Education Research: Approaches and Methods. $2^{\text {nd }}$ edition, Hong Kong: Comparative Education Research Centre, The University of Hong Kong, and Dordrecht: Springer.

Brock, Colin \& Alexiadou, Nafsika (2013): Education Around the World: A Comparative Introduction. London: Bloomsbury. 
Clark, Burton R. (1987): The Academic Life: Small Worlds, Different Worlds. Princeton: The Carnegie Foundation for the Advancement of Teaching.

Cook, Bradley J.; Hite, Steven J. \& Epstein, Erwin H. (2004): 'Discerning Trends, Contours, and Boundaries in Comparative Education: A Survey of Comparativists and their Literature’. Comparative Education Review, 48 (2): 123-149.

Coser, Lewis (1965): Men of Ideas. New York: Free Press of Glencoe.

Cowen, Robert (1990): 'The National and International Impact of Comparative Education Infrastructures', in Halls, W.D. (ed.), Comparative Education: Contemporary Issues and Trends. Paris: UNESCO and London: Jessica Kingsley, pp.321-352.

Crane, Diana (1972): Invisible Colleges: Diffusion of Knowledge in Scientific Communities. Chicago: University of Chicago Press.

Crossley, Michael \& Watson, Keith (2011): 'Comparative and International Education: Policy Transfer, Context Sensitivity and Professional Development', in Furlong, John \& Lawn, Martin (eds.), Disciplines of Education: Their Role in the Future of Education Research. London: Routledge, pp.103-121.

Delanty, Gerard (2001): Challenging Knowledge: The University in the Knowledge Society. Buckingham: The Society for Research into Higher Education \& Open University Press.

Denman, Brian D. \& Higuchi, Satoshi (2013): 'At a Crossroads? Comparative and International Education Research in Asia and the Pacific'. Asian Education and Development Studies, 2 (1): 4-21.

Epstein, Erwin H. (1981): 'Toward the Internationalization of Comparative Education: A Report on the World Council of Comparative Education Societies'. Comparative Education Review, 25 (2): 261-271.

Furlong, John (2013): Education - An Anatomy of the Discipline: Rescuing the University Project?. Abingdon: Routledge.

Furlong, John \& Lawn, Martin (2011): 'The Disciplines of Education: Between the Ghost and the Shadow', in Furlong, John \& Lawn, Martin (eds.), Disciplines of Education: Their Role in the Future of Education Research. London: Routledge, pp.1-12.

Karunaratne, Sunethra (2013): 'Presidential Address', Third Conference of the Indian Ocean Comparative Education Society (IOCES), Khon Kaen University Thailand, 21 January.

Keoun, Dongtaik (2013): Electronic mail correspondence with Mark Bray, 6 and 7 June, 2013.

Klein, Julie Thompson (1990): Interdisciplinarity: History, Theory, and Practice. Detroit: Wayne State University Press.

Kuhn, Thomas (1962): The Structure of Scientific Revolutions. Chicago: University of Chicago Press.

Lê Thành Khôi (1986): ‘Toward a General Theory of Education’. Comparative Education Review, 30 (1), $12-29$.

Lee, Byung-Jin \& Kwon, Dong-Taik (2007): 'The Korean Comparative Education Society (KCES)', in Masemann, Vandra; Bray, Mark \& Manzon, Maria (eds.), Common Interests, Uncommon Goals: Histories of the World Council of Comparative Education Societies and its Members. Hong Kong: Comparative Education Research Centre, The University of Hong Kong, and Dordrecht: Springer, pp.183-188.

Lenoir, Timothy (1993): 'The Discipline of Nature and the Nature of Disciplines’, in Messer-Davidow, Ellen; Shumway, David \& Sylvan, David (eds.), Knowledges: Historical and Critical Studies in Disciplinarity. Charlottesville: University Press of Virginia, pp.70-102.

Macedo, Donaldo; Gounari, Panayota \& Dendrinos, Bessie (2003): The Hegemony of English. Boulder: Paradigm.

Manzon, Maria (2011): Comparative Education: The Construction of a Field. Hong Kong: Comparative Education Research Centre, The University of Hong Kong, and Dordrecht: Springer. 
Manzon, Maria \& Bray, Mark (2007a): 'Comparing the Comparers: Patterns, Themes and Interpretations', in Masemann, Vandra; Bray, Mark \& Manzon, Maria (eds.), Common Interests, Uncommon Goals: Histories of the World Council of Comparative Education Societies and its Members. Hong Kong: Comparative Education Research Centre, The University of Hong Kong, and Dordrecht: Springer, pp.336-363.

Manzon, Maria \& Bray, Mark (2007b): ‘Completing the Family Picture’, in Masemann, Vandra; Bray, Mark \& Manzon, Maria (eds.), Common Interests, Uncommon Goals: Histories of the World Council of Comparative Education Societies and its Members. Hong Kong: Comparative Education Research Centre, The University of Hong Kong, and Dordrecht: Springer, pp.316-335.

Masemann, Vandra; Bray, Mark \& Manzon, Maria (eds.) (2007): Common Interests, Uncommon Goals: Histories of the World Council of Comparative Education Societies and its Members. Hong Kong: Comparative Education Research Centre, The University of Hong Kong, and Dordrecht: Springer.

McLaughlin, Juliana (2013): 'President’s Report', ANZCIES Newsletter, May, pp.1-2

Mochida, Kengo (2007): 'The Comparative Education Society of Asia (CESA)', in Masemann, Vandra; Bray, Mark \& Manzon, Maria (eds.), Common Interests, Uncommon Goals: Histories of the World Council of Comparative Education Societies and its Members. Hong Kong: Comparative Education Research Centre, The University of Hong Kong, and Dordrecht: Springer, pp.309-315.

Ninomiya, Akira (2007): 'The Japan Comparative Education Society (JCES)', in Masemann, Vandra; Bray, Mark \& Manzon, Maria (eds.), Common Interests, Uncommon Goals: Histories of the World Council of Comparative Education Societies and its Members. Hong Kong: Comparative Education Research Centre, The University of Hong Kong, and Dordrecht: Springer, pp.128-138.

Rust, Val D. (2002): 'Editorial: The Place of International Education in the Comparative Education Review'. Comparative Education Review, 46 (3): iii-iv.

Singh, R.P. (2009): 'Review of Common Interests, Uncommon Goals: Histories of the World Council of Comparative Education Societies and its Members [Eds. Masemann, Bray \& Manzon]', Journal of Educational Planning and Administration, XXIII (1): 77-79.

Siribanpitak, Pruet (2013): Electronic mail correspondence with Mark Bray, 30 May, 2013.

Takayama, Keita (2013): 'Rethinking the 'Global Dialogue' from Asia: Implications of Comparative EducationS'. Presentation at the Comparative Education Seminar "Comparatively Rethinking Shadow Education in New Times”, 17 November, Sophia University, Tokyo.

Tietze, Susanne \& Dick, Penny (2013): 'The Victorious English Language: Hegemonic Practices in the Management Academy’. Journal of Management Inquiry, 22 (1), 122-134.

Trowler, Paul (2011): 'Rethinking Academic Tribes and Territories'. University World News, Issue 198, 20 November.

Trowler, Paul; Saunders, Murray \& Bamber, Veronica (eds.) (2012): Tribes and Territories in the $21^{\text {st }}$ Century: Rethinking the Significance of Disciplines in Higher Education. London: Routledge.

Wagner, Peter \& Wittrock, Björn (1991a): 'Analyzing Social Science: On the Possibility of a Sociology of the Social Sciences’, in Wagner, Peter; Wittrock, Björn \& Whitley, Richard (eds.), Discourses on Society: The Shaping of the Social Science Disciplines. Dordrecht: Kluwer Academic Publishers, pp.3-22.

Wilson, David N. (1994): 'Comparative and International Education: Fraternal of Siamese Twins? A Preliminary Genealogy of our Twin Fields’. Comparative Education Review, 38 (4), 449-486.

World Council of Comparative Education Societies [WCCES] (1996): Statutes. http://www.wcces.com/WCCES-Statutes.pdf accessed 23 November 2013.

World Council of Comparative Education Societies [WCCES] (2005): By-laws. http://www.wcces.com/WCCES-By-Laws.pdf accessed 23 November 2013.

World Council of Comparative Education Societies [WCCES] Admissions \& New Societies Standing Committee (2010): 'Report to the World Council of Comparative Education Societies' for $43^{\text {rd }}$ meeting of 
the Executive Committee, Istanbul, Turkey. 